\title{
A Note on Transcriptions, Transliterations, Translations, and Abbreviations
}

I have transcribed all Japanese names, titles, poems, and text excerpts as found in the cited sources. Transliterations are in standard Hepburn Romanization format except for the particle distinguish it and its functions from those of お $(o)$. In transliterations of Japanese poems, I also retain orthography as found in the cited modern editions, which preserve the spellings in those manuscripts on which these editions are based. Japanese names are given in traditional format, that is, surname followed by personal name, with the inclusion of the attributive particle no where used according to convention in Japanese sources for persons of rank or distinction in the past (e.g., Fujiwara no Shunzei).

As is also customary, I refer to literary and other historical personages of the past by their personal names, and many of these appellations use, as is traditional, the Sinitic readings of these names: thus, Shunzei, not Toshinari (俊成), and Teika, not Sadaie (定家). (However, in the bibliography I follow the name forms used according to Library of Congress cataloging protocols.) I render the name of the scholar Origuchi Shinobu as it appears in the catalogs of the National Diet Library (Kokuritsu Kokkai Toshokan), although it frequently appears in publications and indices as "Orikuchi."

All translations are my own unless otherwise indicated.

I have rendered the term Tennō, for the Japanese sovereign, as "Emperor" when referring to those individuals because this is the term most 
familiar to nonspecialist readers of studies of Japanese history and culture, but I recognize that many specialists prefer other renderings; I have also used the term "sovereign" when referring to but not translating a term for the occupant of this office as well as "royal" for properties and practices associated with the same. A number of emperors' names contain the element Go-, indicating "the latter-day..." or "the second ..."; I render these names as GoToba, GoShirakawa, and so on.

I have not translated place-names except in some poems where doing so helps to achieve a better understanding of the figural scheme of the poem in question. My translations of poems do not attempt to recreate their metrical schemes but are intended, likewise, to suggest how these poems work as poems; I do not claim to have made any attempt to create equally poetic versions but rather versions that abet my explanatory and interpretive tasks.

Definitions of Japanese terms and their forms in Japanese scripts, titles of texts in Japanese and Chinese, and names, in Japanese and Chinese script, may be found in the glossaries. In most cases, Japanese terms that occur frequently in the text (such as waka) are italicized only at the first occurrence.

Citations of standard texts use the following abbreviations:

- For classical anthologies of poems:

MYS Man'yōshū

KKS Kokin wakashū

SKKS Shin kokin wakashū

- For standard modern critical editions of premodern texts in various series:

NKBT Nihon koten bungaku taikei. 102 volumes. Tokyo: Iwanami Shoten, 1957-68. Digital version available online via Kokubungaku Kenkyū Shiryōkan, http://base3.nijl.ac.jp/.

SKT Shinpen kokka taikan. 10 volumes plus indices. Ed. Shinpen kokka taikan Henshū Iinkai. Tokyo: Kadokawa Shoten, 1983-92. CD-ROM version 2, 2003, Kadokawa Shoten. 
Digital version available online via Koten Library, http:// kjsystems.sakura.ne.jp/kotenlibrary/.

SNKBT Shin Nihon koten bungaku taikei. 106 volumes. Tokyo: Iwanami Shoten, 1989-2005.

SNKBZ Shinpen Nihon koten bungaku zenshū. 88 volumes. Tokyo: Shōgakkan, 1997-2001. Digital version available online via Japan Knowledge, http://japanknowledge.com/library/. 
This page intentionally left blank 
Waka and Things,

Waka as Things 
This page intentionally left blank 